Author: William Carruthers, Gerda Henkel Stiftung postdoctoral Research Scholar/Visiting Guest Scholar, German Historical Institute London, United Kingdom; carruthers@ ghil.ac.uk

\title{
Rule of Objects: On the De-Peopling of Safe Havens ${ }^{1}$
}

\author{
William Carruthers; German Historical Institute London
}

\begin{abstract}
This article considers a recent initiative to launch cultural property 'safe havens': places which can be used to protect cultural property threatened by terrorism and armed conflict. The article criticises this action, particularly in terms of the way in which it removes local populations and human agency from discussion of the potential workings of these locations. To do so, the article draws a comparison with UNESCO's International Campaign to Save the Monuments of Nubia during the 1960s and 1970s, which similarly removed local populations from its work. Meanwhile, the article also questions the morality of protecting cultural property from destruction while failing to protect populations subject to warfare and terrorism from the same fate. Finally, the article suggests some possible solutions to this problematic situation.
\end{abstract}

Keywords: Cultural property, safe havens, people, UNESCO, Nubia, Syria.

What does it mean to be 'safe,' and what does it mean to be 'endangered'? Who defines these terms, why, and what does this act of definition allow them to do? In December 2016, a conference entitled "Safeguarding Endangered Cultural Heritage" took place in Abu Dhabi, organised jointly by the governments of the United Arab Emirates and France, and held under the patronage of UNESCO. The Crown Prince of Abu Dhabi, Shaykh Mohammed bin Zayed 
Al Nahyan, was in attendance, as was French President François Hollande and the DirectorGeneral of UNESCO, Irina Bokova; many other dignitaries joined them. The diplomatic spectacle was a sight to behold. The assembled, distinctly elite, group seemed to have given itself sole authority to speak for and about cultural heritage around the world.

In this short piece, I want to reflect on the ramifications of this situation, not least because the pronouncements emanating from the conference's podium were so attention-grabbing. Al Nahyan stated that "the destruction of heritage sites by terrorist groups, and illicit trafficking by groups that aim to obliterate the international heritage of humanity, are rejected by all God-given religions and human nature." Not to be outdone, Hollande, discussing the policies put forward at the conference, announced that "this work is part of the battle led by France and the UAE against obscurantism, for openness and culture." As part of this "battle," the conference proposed setting up a global network of 'safe havens' to protect cultural property endangered by terrorism and armed conflict, a proposal closely resembling the 2015 Protocols for Safe Havens for Works of Cultural Significance from Countries in Crisis issued by the Association of Art Museum Directors (AAMD), which allow “"owners' of material in jeopardy ... [to] request that a participating AAMD member museum hold the material until it can be safely returned" (Kersel 2016-2017, 4). The conference also proposed an international fund to help the financing of initiatives connected to this work. As The Art Newspaper reported, "France has started the fund off with $\$ 30 \mathrm{~m}$, the UAE has added $\$ 15 \mathrm{~m}$, and it is expected that public and private contributions will take it to at least $\$ 100 \mathrm{~m}$ " (Cocks 2016).

Through these announcements, the conference's attendees suggested something quite striking. As in the case of the capital being used to finance the safe havens proposed by the 
conference, it seems that it is the ability to move freely and liberally—without apparent bother from regulatory or legislative obstacles - that now defines the effective status and existence of cultural objects, at least according to a certain brand of international diplomacy. If governments and international agencies are able to establish the conditions within which this circulation can take place, it almost seems as if artefacts should find their way to safe havens themselves; 'owners' (presumably, in this instance, implying nation-states) should see the benefits of the situation at once and let the system get on with its work unencumbered. Simultaneously, the people who dwell with such items on an everyday basis, giving these things their meaning, are left out of the equation. People who have a significant claim to the 'ownership' and definition of cultural objects are ignored, even as they too are threatened with life-changing — and life-ending — destruction by conflict and terrorism.

We have been close to this sort of situation before, a state of affairs whose consequences are worth reflecting on. UNESCO at least partially built the authority of its 1972 World Heritage Convention on the work conducted during the 1960s and 1970s as part of its International Campaign to Save the Monuments of Nubia. The Campaign, whose most famous acts remain the transfer of the temples at Abu Simbel and Philae to locations above the floodwaters of the Aswan High Dam, was itself dependent on a trust fund, and partially predicated on the negotiated ability of monuments and excavated objects to move to places — and countriesother than where archaeologists excavated them. The end result of this process, as Lucia Allais $(2012,208)$ has noted, enabled UNESCO to represent itself as having created and set into circulation new and logical "patterns of mobility for knowledge, people, and capital" at a remove from the geopolitics of the High Dam itself. 
The problem is that it takes an enormous suspension of disbelief to concur not only that these patterns worked as easily and apolitically as UNESCO likes to purport, but also that they were not instead dependent on human interactions, choices, and asymmetries throughout their effective lifespan. For instance, the construction of the Aswan High Dam-as well as being responsible for the deaths of many labourers - was also dependent on the movement of an entire, geopolitically divided population away from monuments and archaeological remains, which were consequently recorded (as was the norm) as free from human contact. A separate, Ford Foundation-funded ethnological campaign surveyed the lives of Egyptian Nubians before they were relocated northwards (Hopkins and Mehanna 2010). But the Sudanese Nubians, bar a census and a statistical survey predicated on making their own emigration southwards as efficient as possible (Dafalla 1975), apparently warranted less effort. Everyone in Nubia was equal, but some people seemed to be more equal than others.

The consequences of this situation are fairly striking, not least in the way that the Nubian 'right-to-return' has become an increasingly live political issue (Janmyr 2016). Meanwhile, last summer, I came across a display panel in the National Museum in Warsaw detailing how the institution "acquired 67 wall paintings," among various other objects from Nubia. The rest of the artefacts from Polish work during the Nubian campaign, the panel informs us, "found their way to the Sudan National Museum in Khartoum" (fig. 1). But for anything to 'find its way' required conversations between archaeologists and government officials and a division of excavated artefacts to be decided on and take place. It also required the Nubians who lived in and around the places where these things were excavated to acquiesce to their state-appointed fates. Giving the Warsaw objects agency removes the reality that this agency was produced by human beings making choices and having choices enacted upon them. It removes the objects on display from the human interactions that gave — and give - them 
meaning. The situation is a bit, one might suggest, like that of an apparently freewheeling object on its way to a safe haven.

There are difficult questions at stake here. Morag Kersel has discussed the positives and negatives of cultural property safe havens in detail, also noting that "there is no doubt that landscapes, museums, and artifacts across [in this instance] the Middle East face ongoing threats" (2016-2017, 14). No one would deny that things are threatened, even as it is the act of digging, whether archaeological excavation or looting, that turns things into the cultural property on which this threat is enacted. But how has the particular assemblage of institutions, objects, capital, and people represented by the Nubian campaign once again come together in the form of the Abu Dhabi conference? How is it possible to suggest the efficacy of the cultural property "safe haven" at the same time as other immanent safe havens have so obviously failed to come into being? Why is it possible to 'save' things, but not save the relationship of things to the people that give them meaning, and not, in fact, save people at all?

In Aleppo, two weeks after the "Safeguarding Endangered Cultural Heritage" conference took place, the devastated city's remaining inhabitants were waiting for the Assad regime's Russian-backed forces to close in. At best, reports were desperate. At worst, they involved summary executions and Syrians recording, online, what they feared would be their final moments. Even as organisations like the International Red Cross called for controlled evacuations to take place, safe havens were sorely lacking. Much of the world had been able to demonstrate its concern for a dehumanised representation of ancient Palmyra that erased contemporary Tadmur, the location of the site, from existence. ${ }^{2}$ Somehow, though, the people of contemporary Aleppo were treated differently. 
And here lies the final, grim irony. By appropriating the terminology of warfare and creating "safe spaces" for cultural property, we not only create a dubious moral equivalence between sites, objects, and the people who live in and around them. By dehumanising representations of such places, we also take that equivalence away at the same time as we dehumanise the refugees and others who we have collectively failed to assist. Cultural property can now move more freely — and, as a commodity, is often valued more highly — than people, whether in terms of the sort of initiative announced in Abu Dhabi or in terms of the art market that helps to fuel looting. We let some goods keep on moving and classify other, human 'goods' as not good at all.

We need to re-think our priorities, and to do so in a way that considers the lives of people above all else. Taking humanitarian crisis into consideration, neither international conferences attended by a select group of diplomats nor the freewheeling capital pledged at them are sufficient to address what it means for something — or someone — to be safe. Objects on their way to well-financed safe havens are objects torn from meaning unless their relationship to people is made explicit, and unless the people who have helped make their meaning are not only safe, but also part of the conversation. If cultural property safe havens are going to exist (and it certainly seems as if they will exist, at least in the near future) ${ }^{3}$ then their existence needs to be coupled to the ongoing existence of the lives connected to the objects stored in them. For all their rhetoric about saving the heritage of humanity, historical events like the Nubian campaign failed to conceive of cultural property as connected to people. There is no reason to make the same mistake again.

\footnotetext{
${ }^{1}$ This is an edited, re-worked version of a piece originally published on my personal blog at http://williamcarruthers.wordpress.com on December 192016.

${ }^{2}$ A point made forcefully by Michael Press (2016), for instance.

${ }^{3}$ The fund launched at the Abu Dhabi conference has, at the time of writing, raised $\$ 75$ million (Noce 2017).
} 


\section{Works Cited}

Allais, Lucia. 2012. “The Design of the Nubian Desert: Monuments, Mobility, and the Space of Global Culture." In Governing by Design: Architecture, Economy, and Politics in the Twentieth Century, edited by Aggregate (Architectural History Collaborative), 179-215. Pittsburgh, PA: University of Pittsburgh Press.

Cocks, Anna Somers. 2016. “Iconoclasm Rejected by ‘All God-Given Religions', Declares the Crown Prince of Abu Dhabi." The Art Newspaper (online), 5 December. Accessed 7 March 2017, http://theartnewspaper.com/news/iconoclasm-rejected-by-all-god-givenreligions-declares-the-crown-prince-of-abu-dhabi/

Dafalla, Hassan. 1975. The Nubian Exodus. London: C Hurst \& Company, in association with the Scandinavian Institute of African Studies, Uppsala.

Hopkins, Nicholas, and Sohair Mehanna, eds. 2010. Nubian Encounters: The Story of the Nubian Ethnological Survey 1961-1964. Cairo: The American University in Cairo Press. Janmyr, Maja. 2016. "Nubians in Contemporary Egypt: Mobilizing Return to Ancestral Lands." Middle East Critique 25 (2), 127-146.

Kersel, Morag. 2016-2017. “Acquisition Apologetics: A Case for Saving the Past for the Future?" Brown Journal of World Affairs 23 (1), 1-18 [page numbers refer to final proof version]. 
Noce, Vincent. 2017. “Global Fund to Protect Cultural Heritage Launches with \$75m and Board Led by US Billionaire Thomas Kaplan.” The Art Newspaper (online), 20 March. Accessed 22 March 2017, http http://theartnewspaper.com/news/news/global-fund-to-protectcultural-heritage-launches-with-75m-and-board-led-by-us-billionaire-thomas-ka/

Press, Michael. 2016. "Callousness among the Ruins.” Textual Cultures, Material Cultures (online blog), 31 March. Accessed 22 March 2017, http://textualcultures.blogspot.co.uk/2016/03/callousness-among-ruins.html

\section{Figures}

Caption for Figure 1: Display panel, National Museum in Warsaw, Poland (photo copyright William Carruthers 17 June 2016). 